\title{
LUMBAR ENDOSCOPIC DISCECTOMY IN OBESE PATIENTS
}

\author{
DISCECTOMIA ENDOSCÓPICA LOMBAR EM PACIENTES OBESOS
}

DISCECTOMÍA ENDOSCÓPICA LUMBAR EN PACIENTES OBESOS

\author{
Leonardo Yukio Jorge Asano, ${ }^{1}$ Gustavo Bisson, ${ }^{1}$ Danilo Gianuzzi, ${ }^{1}$ João Paulo Machado Bergamaschi, ${ }^{2}$ Álvaro Dowling, ${ }^{2}$ Luciano Miller Reis Rodrigues ${ }^{1}$ \\ 1. Faculdade de Medicina do ABC, Santo André, SP, Brazil. \\ 2. Clínica Kennedy, São Paulo, SP, Brazil.
}

\begin{abstract}
Objective: The aim of this study was to evaluate the clinical and functional results of endoscopic lumbar discectomy in obese patients. Methods: We selected 56 patients with lumbar disc hernia refractory to clinical treatment that underwent endoscopic discectomy. Twenty-five patients with a body mass index (BMI) greater than or equal to $30 \mathrm{~kg} / \mathrm{m}^{2}$ were analyzed through the Visual Analogue Scale and functional evaluation using the Oswestry Disability Index questionnaire and compared to 31 patients in the control group (BMI between 18.5 and 24.9 $\mathrm{kg} / \mathrm{m}^{2}$ ). These data were obtained in the preoperative period, in the immediate postoperative period, at 1 month, 3 months, 6 months and one year after surgery. Results: The mean BMl in the control group was $22.1 \mathrm{~kg} / \mathrm{m}^{2}$, and in the obese group, $33.6 \mathrm{~kg} / \mathrm{m}^{2}$. In both groups there was a statistically significant improvement in clinical and functional analyzes. There was no statistical difference between the groups. Conclusions: Lumbar transforaminal endoscopic discectomy has been shown to be a safe, effective and minimally invasive alternative for the treatment of lumbar disc herniation in obese patients. Level of Evidence III; Retrospective and Comparative Study.
\end{abstract}

Keywords: Intervertebral disc displacement; Diskectomy, Percutaneous; Endoscopy; Minimally Invasive Surgical Procedures; Obesity.

\section{RESUMO}

Objetivo: A meta do estudo foi avaliar os resultados clínicos e funcionais da discectomia endoscópica lombar nos pacientes obesos. Métodos: Foram selecionados 56 pacientes portadores de hérnia de disco lombar refratário ao tratamento clínico submetidos à discectomia endoscópica. Através de avaliação clínica - pela Escala Visual Analógica - e funcional - pelo questionário de Oswestry Disability Index. Foram analisados 25 pacientes com índice de massa corpórea (IMC) maior ou igual de $30 \mathrm{~kg} / \mathrm{m}^{2}$ e comparados com 31 pacientes do grupo controle (IMC entre 18,5 e 24,9 kg/m²). Esses dados foram obtidos no período pré-operatório, no pós-operatório imediato, com 1 mês, 3 meses, 6 meses e um ano após a cirurgia. Resultados: O IMC médio no grupo controle foi de 22,1 kg/m², e no grupo obeso de $33,6 \mathrm{~kg} / \mathrm{m}^{2}$. Em ambos os grupos houve melhora estatisticamente significativa nas análises clínicas e funcionais. Não se observou diferença estatística entre os grupos. Conclusão: A discectomia endoscópica transforaminal lombar mostrou ser uma alternativa segura, efetiva e minimamente invasiva para o tratamento de hérnia de disco lombar em pacientes obesos. Nível de Evidência III; Estudo Retrospectivo, Comparativo.

Descritores: Deslocamento do Disco Intervertebral; Discotomia Percutânea; Endoscopia; Procedimentos Cirúrgicos Minimamente Invasivos; Obesidade.

\section{RESUMEN}

Objetivo: El objetivo de este estudio fue evaluar los resultados clínicos y funcionales de la discectomía lumbar endoscópica en pacientes obesos. Métodos: Se seleccionaron 56 pacientes portadores de hernia discal lumbar refractaria al tratamiento clínico, sometidos a discectomía endoscópica. Se analizaron 25 pacientes con índice de masa corporal (IMC) mayor o igual a $30 \mathrm{~kg} / \mathrm{m}^{2}$ ) por medio de la Escala Visual Analógica y evaluación funcional mediante el cuestionario Índice de Discapacidad de Oswestry y se compararon a 31 pacientes del grupo control (IMC entre 18,5 kg/m y 24,9 kg/m²). Estos datos fueron obtenidos en el preoperatorio, en el postoperatorio inmediato, al mes, a los 3 meses, 6 meses y un año después de la cirugía. Resultados: El IMC promedio en el grupo control fue de $22,1 \mathrm{~kg} / \mathrm{m}^{2}$ y en el grupo obeso, de 33,6 kg/m². En ambos grupos hubo una mejoría estadísticamente significativa en los análisis clínicos y funcionales. No hubo diferencia estadística entre los grupos. Conclusiones: La discectomía endoscópica transforaminal lumbar se ha mostrado una alternativa segura, eficaz y mínimamente invasiva para el tratamiento de hernia discal lumbar en pacientes obesos. Nivel de Evidencia III; Estudio Retrospectivo y Comparativo.

Descriptores: Desplazamiento del Disco Intervertebral; Discectomía Percutánea; Endoscopía; Procedimientos Quirúrgicos Mínimamente Invasivos; Obesidad.

\section{INTRODUCTION}

Obesity is a global health issue and its prevalence is increasing. In relation to the spine, obesity is associated with overload, especially in the lumbar region, causing damage to the integrity of the intervertebral discs. Therefore, a high body mass index has been implicated as a risk factor for lumbar disc degeneration. Obese patients are more likely to have radicular pain, neurological alterations, and disc herniations. ${ }^{1,2}$
Surgical treatment in obese patients requires a wide incision to permit an adequate deep visualization, thus causing greater damage to the paravertebral muscles and greater perioperative morbidity. ${ }^{3}$

Endoscopic lumbar discectomy has been developed as a minimally invasive technique for disc herniation, offering several advantages, such as less tissue damage with the preservation of 
the paravertebral muscles, a shorter hospitalization time, lower morbidity, and an early return to activities. ${ }^{4}$

This study evaluated the clinical and functional results of endoscopic discectomies in obese patients with lumbar disc herniation.

\section{METHODS}

Obesity was defined by the body mass index (BMI), which is calculated by divided body weight in kilograms by the height in meters squared $\left(\mathrm{Kg} / \mathrm{m}^{2}\right)$. Patients with a BMl equal to or greater than $30 \mathrm{Kg} / \mathrm{m}^{2}$ were considered obese.

A total of 100 patients underwent endoscopic transforaminal lumbar discectomy between April 2015 and April 2016 for lumbar disc herniation refractory to clinical treatment. This study compared the clinical findings of the obese patients (BMl greater than $30 \mathrm{Kg} / \mathrm{m}^{2}$ ) with those of patients with a normal BMl (between 18.5 and $24.9 \mathrm{Kg} / \mathrm{m}^{2}$ ). This study was submitted to and approved by the Institutional Review Board of the Faculdade de Medicina do ABC (CAAE 85551418.0.000.0082). All patients signed the Informed Consent Form.

Patients with BMl between 25 and 29.9 were considered overweight and were excluded. In addition, severe lumbar stenosis, spondylolisthesis, tumor, trauma, and infection were exclusion criteria.

Patients with disc herniation defined in magnetic resonance images, associated with a positive test for nerve root pressure in the physical examination, and persistent sciatic pain after more than six weeks of appropriate conservative treatment (physical therapy, analgesia, rest) were included.

Patients were assessed for clinical data for pain using the $\mathrm{Vi}$ sual Analog Scale (VAS) and in terms of functional findings by the Oswestry Disability Index (ODI). These data were obtained in the preoperative and immediate postoperative periods and at 1 month, 3 months, 6 months, and 1 year following surgery. During follow-up, the patients who evolved with persistence of or new symptoms of radicular pain underwent a new magnetic resonance examination.

A significance level of $5 \%(0.050)$ was adopted for the application of statistical tests, that is, when the significance value calculated (p) was less than $5 \%$, a statistically significant relationship was observed, but when the $p$-value was greater than $5 \%$, a so-called non-statistically significant relationship was identified. The SPSS (Statistical Package for Social Sciences) program, version 13.0, was used to obtain results. The Mann-Whitney $U$ test was used to compare the two groups at the clinical (VAS) and functional (ODI) levels. The Wilcoxon signed rank test was applied as a complementary test to identify which moments of observation differed the most from the others.

As regards the surgical technique, the patient is positioned in a prone position on a radio-transparent table, with the hips and knees flexed, under conscious sedation. After adequate asepsis, the skin is marked assisted by fluoroscopic visualization. Then, local anesthesia is performed with $1 \%$ xylocaine without a vasoconstrictor at the established puncture site. An 18 gauge needle is introduced up to the lateral portion of the facet joint and then to the posterior surface of the annulus fibrosus, locations where additional anesthetic is applied. Discography is performed with a solution of non-iodized contrast and methylene blue. Then the guide-wire, dilator, and working cannula are introduced, followed by an endoscope with 30 degrees of angulation and continuous flow irrigation. In case of bleeding, hemostasis is performed with a bipolar coagulator. The herniated disc fragment is identified with blue coloration and delicately removed with specific tweezers. It is generally possible to observe the release of the nerve root with oscillation of the irrigation pressure. The patients are permitted to walk when they are completely recovered from the sedation.

\section{RESULTS}

A total of 56 patients were included in the study, 25 of whom were obese. In the control group, the 31 patients, 15 of whom were men and 16 of whom were women, had a mean BMl of $22.1 \mathrm{Kg} / \mathrm{m}^{2}$ (ranging from 19.3 to 24.8). Table 1 shows the demographic and clinical data of the obese and control groups. In both groups, the disc level most affected was L4-L5, followed by L5-S1. Fifteen patients were operated at two levels, eight from the obese group and seven from the control group.

The duration of the surgical procedure and hospitalization time were not statistically different between the groups. The mean surgical time was 53 minutes in both groups and everyone was discharged within a maximum of 12 hours following discectomy.

The preoperative and postoperative follow-up clinical and functional findings of the obese and control groups can be observed in Figure 1 and Figure 2, respectively. The comparison between the obese and control groups in terms of the VAS questionnaire scores are shown in Table 2, and in terms of the ODI questionnaire scores, in Table 3.

No accidental dural lesions, neurological damage, or disc or surgical site infections were observed in any of the 56 patients. There were 3 cases of disc herniation recurrence at the same level after a period of significant improvement of symptoms, 2 of them in the obese group and 1 in the control group. Of these cases, only 1 patient (control group) required a new endoscopic discectomy. There were no conventional microdiscectomies performed for the disc herniation recurrences. Tolerable sciatic pain was observed in 5 patients ( 2 in the obese group and 3 in the control group) with good improvement after conservative treatment.

Table 1. Demographic and clinical characteristics.

\begin{tabular}{c|c|c}
\hline & Obese group & Control group \\
\hline Number of patients & 25 & 31 \\
\hline Age (mean) & 48.8 & 48.6 \\
\hline Male/Female & $15 / 10$ & $15 / 16$ \\
\hline Mean BMI (Kg/m ${ }^{2}$ ) & 33.6 & 2.1 \\
\hline Surgical level & & \\
\hline L3-L4 & 2 & 2 \\
\hline L4-L5 & 19 & 16 \\
\hline L5-S1 & 11 & 19
\end{tabular}

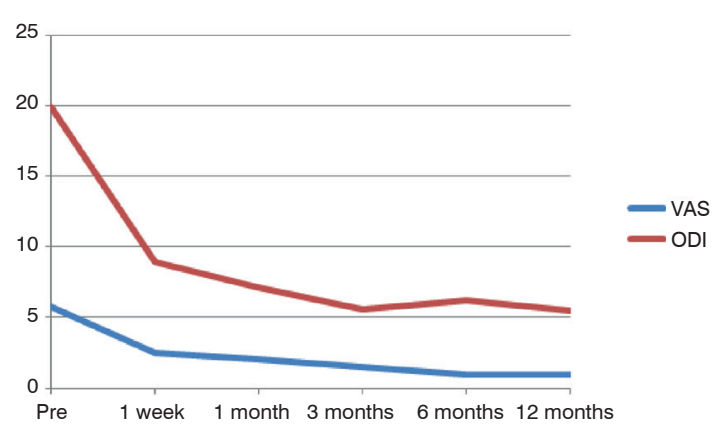

Figure 1. Questionnaires for the obese group during follow-up.

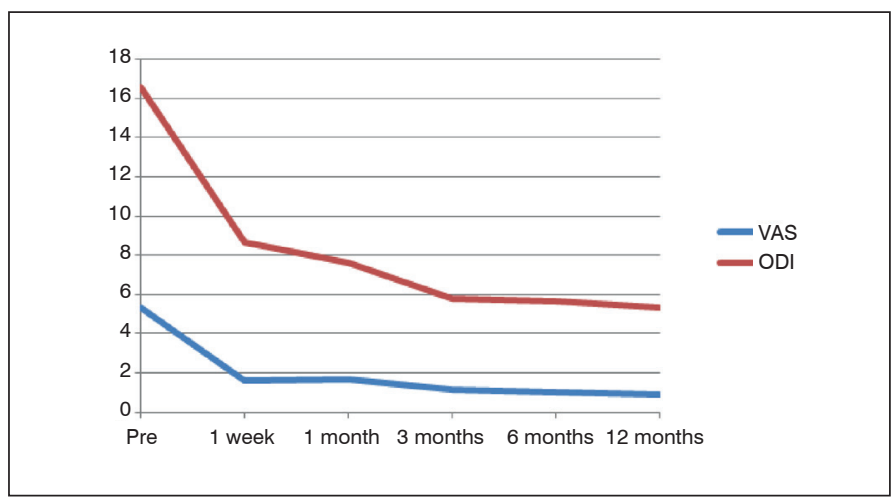

Figure 2. Questionnaires for the control group during follow-up. 
Table 2. Visual Analog Scale Questionnaire.

\begin{tabular}{c|c|c|c|c|c|c}
\hline & \multicolumn{3}{|c|}{ VAS (lumbar) } & \multicolumn{3}{c}{ VAS (leg) } \\
\hline & Obese & Control & $\mathbf{p}^{*}$ & Obese & Control & $\mathbf{p}^{*}$ \\
\hline Pre & 5.46 & 6.32 & 0.758 & 5.79 & 4.65 & 0.197 \\
\hline 1 week & 2.46 & 2.32 & 0.754 & 2.21 & 1.58 & 0.703 \\
\hline 1 month & 2.08 & 2.45 & 0.371 & 1.63 & 1.68 & 0.902 \\
\hline 3 months & 1.96 & 2.42 & 0.443 & 1.52 & 1.13 & 0.368 \\
\hline 6 months & 2.42 & 2.06 & 0.761 & 2.13 & 1.03 & 0.103 \\
\hline 12 months & 2.21 & 2.32 & 0.771 & 1.63 & 0.90 & 0.228 \\
\hline $\mathrm{p}^{* *}$ & $<0.001$ & $<0.001$ & & $<0.001$ & $<0.001$ & \\
\hline
\end{tabular}

$\mathrm{p}^{*}<0.05=$ statistically significant. $\mathrm{p}^{\star *}=$ Relationship between preoperative and 12 months

Table 3. Oswestry Disability Index Questionnaire.

\begin{tabular}{c|c|c|c}
\hline ODI & Obese & Control & $\mathbf{p}^{*}$ \\
\hline Preoperative & 19.96 & 16.57 & 0.332 \\
\hline 1 week & 8.92 & 8.68 & 0.993 \\
\hline 1 month & 7.13 & 7.65 & 0.225 \\
\hline 3 months & 5.63 & 5.81 & 0.506 \\
\hline 6 months & 6.25 & 5.65 & 0.880 \\
\hline 12 months & 5.46 & 5.32 & 0.686 \\
\hline $\mathrm{p}^{* *}$ & $<0.001$ & $<0.001$ & \\
\hline $\mathrm{p}^{*}<0.05=$ statistically significant. $\mathrm{p}^{* *}=$ Relationship between preoperative and 12 months.
\end{tabular}

\section{DISCUSSION}

Obesity is defined by the World Health Organization as a body mass index greater than or equal to $30 \mathrm{Kg} / \mathrm{m}^{2}$ and is considered to be a public health concern. In the United States, a 2014 study reported a prevalence of $36.5 \%$ in the adult population. ${ }^{5}$ High BMI has been associated with a significant risk of venous thromboembolism, more serious complications, surgical site infections, increased surgical time, and significant socioeconomic impact. ${ }^{6}$

Several studies have associated obesity and being overweight with lumbar pain, demonstrating its active role in the pathogenesis of disc degeneration. ${ }^{7-9}$ Some authors also have identified obesity as a predisposing factor for sciatalgia, increasing the probability of hospitalization and herniated lumbar disc surgery. ${ }^{10}$

Although the worldwide clinical findings in obese patients following lumbar spine surgery are similar to those of the population at a normal weight, the incidence of complications following conventional spine surgery is generally higher in obese patients. Spinal decompression surgery reportedly has a 50\% complication rate in morbidly obese individuals. ${ }^{11}$ This increase in the complications rate can be attributed to the technical difficulties associated with a deep surgical field, resulting in longer procedure times, a higher risk of contamination, and greater trauma to the paravertebral musculature. Dehiscence of the surgical wound is more often observe in obese patients, probably due to the increased pressure of the margins of the wound at the time of suturing and/or the existence of a hematoma or seroma. ${ }^{3,12-17}$

Obese patients can benefit significantly from spinal surgery,

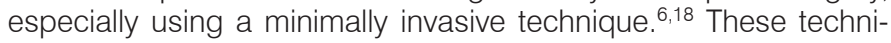
ques provide a beneficial alternative for obese patients, minimizing postoperative complications. ${ }^{19}$

Three studies have reported the results from endoscopic transforaminal lumbar discectomy in obese patients. In 2016, Bae and Less conducted a retrospective study of 21 obese patients and 27 patients with normal BMI and observed similar VAS and ODI results. In both groups there was significant reduction in these parameters after two years of postoperative follow-up. ${ }^{11}$
In the same year, Wang et al. studied the effectiveness of endoscopic transforaminal lumbar discectomy in 67 obese patients with lumbar disc herniation. The evaluation through VAS and the Japanese Orthopedics Association showed significant improvement in the patients between 3 and 12 months of postoperative follow-up. ${ }^{20}$

A cohort study conducted in Greece and published in 2018 compared twenty obese patients with ten patients with normal BMI. After having undergone endoscopic transforaminal lumbar discectomy, they were evaluated for two years using the Short Form SF-36 Medical Survey and VAS questionnaires. Statistically satisfactory results were observed in both groups for all indices evaluated. ${ }^{21}$

As regards the incidence of complications, studies have not reported differences between obese and non-obese patients following endoscopic procedure. Cole et al. observed $9.4 \%$ cases of iatrogenic durotomy in 22 obese patients. ${ }^{22}$ Studies by Bae and Lee and S. Kapetanakis concluded that endoscopic transforaminal discectomy is closely linked to reductions in perioperative infection rates and complications of the wound, which is extremely important in obese patients.

Another complication studied that may follow the endoscopic procedure for lumbar disc herniation is dysesthesia due to probable compression or intraoperative stimulation of the nerve root emerging from the foraminal space, which occurs with significant frequency in obese patients. ${ }^{23}$ Wang et al. reported this complication in 2 of 69 obese patients (2.9\%). In an attempt to minimize the risk of neurological injury, some technical details can be used, such as local anesthesia with lidocaine in the zygapophysial joints and area of the nerve root, gentle removal of the disc tissue, and constant communication between the patient and the spine surgeon during surgery. ${ }^{20,23}$

In our study, 2 patients in the obese group reported dysesthesia after surgery. In these two cases, the endoscopic procedure was performed from a transforaminal approach at two levels (L4L5 and L5-S1). These patients underwent clinical treatment with analgesics and physical therapy with significant improvement after about 40 days.

Our study has limitations because of its retrospective design with one year of postoperative follow-up. The clinical and functional results were considered to be most the most important in follow-up after discectomy and, therefore, the reduction of the herniated disc in the postoperative period was not studied by means of imaging examination since magnetic resonance is only performed for cases of persistence or new sciatalgia symptoms. Studies with a greater number of patients and longer follow-up intervals are necessary to objectively evaluate the impact of endoscopic discectomy in obese patients.

\section{CONCLUSION}

Endoscopic transforaminal lumbar discectomy has proven to be a safe, effective, and minimally invasive alternative for the treatment of lumbar disc herniation in obese patients, with the advantages of significantly reduced damage to the soft tissues, shorter surgical time, and a lower rate of complications.

All authors declare no potential conflict of interest related to this article.

CONTRIBUTION OF THE AUTHORS: Each author made significant individual contribution to this manuscript. LYJA (0000-0002-8489-5256)*, GB $(0000-0001-8784-2283)^{\star}$, DG (0000-0001-6948-3766)*, JPMB (0000-0002-6992-9876)*, AD (0000-0001-9963-4131)*, and LMRR (0000-0001-6891-5395)* were responsible for the manuscript. LMRR, LYJA, JPMB, and AD participated actively in the discussion of the results, analyzed and accompanied each phase of the study, and also participated in the review and final approval of the work. GB was responsible for the elaboration of the initial project and data collection and analysis. LYJA participated in the analysis and discussion of the results and also participated in the review and final approval of the manuscript. *ORCID (Open Researcher and Contributor ID). 


\section{REFERENCES}

1. Fanuele JC, Abdu WA, Hanscom B, Weinstein JN. Association between obesity and functional status in patients with spine disease. Spine (Phila Pa1976). 2002:27(3):306-12

2. Heliovaara M. Body height, obesity, and risk of herniated lumbar intervertebral disc. Spine (Phila Pa 1976). 1987;12(5):469-72.

3. Telfeian AE, Reiter GT, Durham SR, Marcotte P. Spine surgery in morbidly obese patients. J Neurosurg. 2002;97(1 Suppl):20-4

4. Maroon JC. Current concepts in minimally invasive discectomy. Neurosurgery. 2002:51(5 Suppl): S137-45

5. Ogden $\mathrm{CL}$, Carroll MD, Fryar CD, Flegal KM. Prevalence of obesity among adults and youth: United States, 2011-2014. NCHS Data Brief. 2015;(219):1-8.

6. Castle-Kirszbaum MD, Tee JW, Chan P, Hunn MK. Obesity in neurosurgery: a narrative review of the literature. World Neurosurg. 2017;106:790-805.

7. Rihn JA, Kurd M, Hilibrand AS, Lurie J, Zhao W, Albert T, et al. The influence of obesity on the outcome of treatment of lumbar disc herniation: analysis of the Spine Patient Outcomes Research Trial (SPORT). J Bone Joint Surg Am. 2013:95(1):1-8.

8. Pereira BJ, de Holanda CV, Ribeiro CA, de Moura SM, Galvão PE, Quidute BS, et al. Impact of body mass index in spinal surgery for degenerative lumbar spine disease. Clin Neurol Neurosurg. 2014;127:112-5.

9. $\mathrm{Xu} \mathrm{X}, \mathrm{Li} \mathrm{X}, \mathrm{Wu} \mathrm{X}$. Association between overweight or obesity and lumbar disk diseases: a meta-analysis. J Spinal Disord Tech. 2015;28(10):370-6.

10. Shiri R, Lallukka T, Karppinen J, Viikari-Juntura E. Obesity as a risk factor for sciatica: a meta-analysis. Am J Epidemiol. 2014;179(8):929-37.

11. Bae JS, Lee SH. Transforaminal full-endoscopic lumbar discectomy in obese patients. Int J Spine Surg. 2016;10:18

12. Yadla S, Malone J, Campbell PG, Maltenford MG, Harrop JS, Sharan AD, et al. Obesity and spine surgery: reassessment based on a prospective evaluation of perioperative complications in elective degenerative thoracolumbar procedures. Spine J. 2010:10(7):581-7.

13. Shamii MF, Parker S, Cook C, Pietrobon R, Brown C, Isaacs RE. Impact of body habitus on perioperative morbidity associated with fusion of the thoracolumbar and lumbar spine. Neurosurgery. 2009;65(3):490-8; discussion 498.

14. Gepstein R, Shabat S, Arinzon ZH, BernerY, Catz A, Folman Y. Does obesity affect the results of lumbar decompressive spinal surgery in the elderly? Clin Orthop Relat Res. 2004;(426):138-44

15. Wimmer $\mathrm{C}$, Gluch $\mathrm{H}$, Franzreb M, Ogon M. Predisposing factors for infection in spine surgery: a survey of 850 spinal procedures. J Spinal Disord. 1998;11(2):124-8.

16. Andreshak TG, An HS, Hall J, Stein B. Lumbar spine surgery in the obese patient. J Spinal Disord. 1997:10(5):376-9.

17. Hanigan WC, Elwood PW, Henderson JP, Lister JR. Surgical results in obese patients with sciatica. Neurosurgery. 1987;20(6):896-9.

18. Onyekwelu I, Glassman SD, Asher AL, Shaffrey CL, Mummaneni PV, Carreon LY. Impact of obesity on complications and outcomes: a comparison of fusion and nonfusion lumbar spine surgery. J Neurosurg Spine. 2017;26(2):158-62.

19. Goldin AN, Alander DH. Effect of body mass index on early outcomes of minimally invasive degenerative lumbar surgery. J Surg Orthop Adv. 2015;24(1):12-7

20. Wang YP, Zhang W, An JL, Zhang J, Bai JY, Sun YP. Evaluation of transforaminal endoscopic discectomy in treatment of obese patients with lumbar disc herniation. Med Sci Monit. 2016;22:2513-9

21. Kapetanakis $\mathrm{S}$, et al. Percutaneous transforaminal endoscopic discectomy for the treatment of lumbar disc herniation in obese patient: health-related quality of life assessment in a 2-year follow-up. World Neurosurg. 2018;113:e638-49.

22. Cole JS 4th, Jackson TR. Minimally invasive lumbar discectomy in obese patients. Neurosurgery. 2007:61(3):539-44; discussion 544

23. Cho JY, Lee SH, Lee HY. Prevention of development of postoperative dysethesia in transforaminal percutaneous endoscopic lumbar discectomy for intracanalicular lumbar disc herniation: floating retraction technique. Minim Invasive Neurosurg. 2011;54(5-6):214-8. 